\title{
Effect of feeding system and grain source on lactation characteristics and milk components in dairy cattle
}

\author{
M.-C. Ferland, ${ }^{*}$ M.-A. Guesthier, ${ }^{*}$ R. I. Cue, ${ }^{*}$ R. Lacroix, ${ }^{\dagger} \dagger$ S. A. Burgos, ${ }^{*}$ D. Lefebvre, ${ }^{*} \dagger$ and K. M. Wade ${ }^{* 1}$ \\ *Dairy Information Systems Group, Department of Animal Science, McGill University, Ste. Anne de Bellevue, QC, Canada H9X 3V9 \\ †Valacta, Ste. Anne de Bellevue, QC, Canada H9X 3R4
}

\begin{abstract}
The objective of this study was to examine the effect of feeding systems [component and total mixed rations (TMR)] and dietary grain sources (barley, commercial concentrate, corn grain, and high-moisture corn) on lactation characteristics and milk composition. A total of 852,242 test-day records, information on animal characteristics, feed composition, and feeding systems from 104,129 Holstein cows in 4,319 herds covering a period of 5 yr were obtained from Quebec's Dairy Herd Improvement Association (Valacta). We performed descriptive statistics and graphical representations of the data for each type of feeding system and grain source by parity ( 1 to 3 ). The milk records were binned in $15-\mathrm{d}$ in milk blocks. Mixed models using a combination of forward and backward stepwise selections were developed to predict milk and milk component yields. The TMR-fed cows had greater yield of milk, fat, protein, and lactose and lower milk urea N (MUN) concentration than component-fed cows at all parities. Cows fed a TMR had higher peak milk yields and greater persistency after peak lactation compared with componentfed cows. In addition, greater yields of milk fat and protein from peak to mid-lactation were found in TMRversus component-fed cows. In general, greater milk fat and protein yields as well as lower MUN concentration were observed in cows fed corn grain or high-moisture corn compared with barley or commercial concentrate, but parity influenced these relationships. The feeding system by day in milk blocks interaction was significant in models of milk and components yields for all parities, but only for second-lactation cows for MUN concentration. This means that effect of TMR and component feeding differs with stage of lactation. In conclusion, feeding TMR and corn-based diets are associated with greater yield of milk and milk components under commercial conditions.
\end{abstract}

Received September 5, 2017.

Accepted May 8, 2018.

${ }^{1}$ Corresponding author: kevin.wade@mcgill.ca
Key words: milk composition, lactation characteristics, feeding system, grain sources

\section{INTRODUCTION}

Bovine milk composition is of interest to dairy producers, processors, and consumers alike. Indeed, the overall profitability of the entire dairy industry would benefit from matching the production of milk components to their demand (Kennelly and Glimm, 1998; Bittante et al., 2015). This goal has motivated research in manipulation of milk components and prediction of their yield. Three main options exist to alter milk composition: cow nutrition and management, cow genetics, and dairy processing (Walker et al., 2004). Of these, only nutrition allows for relatively rapid changes in the milk composition at the cow level and it is the most suitable method to meet changing market demands.

The method or sequence of feeding can have an effect on milk yield and composition. Feeding forages first has been hypothesized to allow the formation of a fiber mat in the rumen, stimulating salivation and rumen motility (Nocek, 1992; NRC, 2001). Indeed, lower milk fat percentages were observed for cows given supplements on a pasture system compared with cows receiving a TMR (White et al., 2001; Bargo et al., 2002). However, in some studies (Nocek, 1992; Macleod et al., 1994), no effect on rumen fermentation characteristics or milk production was found when legume forages were fed first. Kolver and Muller (1998) observed only a numerical decrease in the milk fat percentage between cows consuming only pasture and those receiving a TMR. Similarly, Ferris et al. (2006) found no effect of feeding system on milk yield, milk fat, or milk protein percentage. Larkin and Fosgate (1970) showed that both component- and TMR-feeding systems have resulted in similar milk protein percentages. Nevertheless, some researchers (Coppock et al., 1981; Hutjens, 1996) have suggested that milk components can increase when cows are fed a TMR When fed twice a day, cows receiving a TMR tended to have greater milk fat percentage than component-fed cows (Kennelly, 1996). 
In addition to feeding systems, the source and conservation method of grains can influence milk composition. According to the NRC (2001), milk fat percentage, ruminal $\mathrm{pH}$, and ruminal VFA profile are altered by increased starch availability in the rumen, even when the concentration of dietary NDF is not changed. Indeed, several studies have reported differences in milk composition in response to the type of grain fed. For example, McCarthy et al. (1989) and Casper et al. (1990) reported greater milk yields for cows fed corn grain as compared with cows fed barley. Kargar et al. (2014) reported a linear increase in milk fat yield when corn replaced barley in oil-supplemented rations. Wilkerson et al. (1997) demonstrated an increase in milk yield for cows fed high-moisture corn versus dry ground corn and found that ruminal digestibility of high-moisture corn was greater than dry ground corn. Similarly, Lykos et al. (1997) showed that increasing the rate of NSC digestion from 6 to $7.9 \% / \mathrm{h}$ increased milk yield by $2.5 \mathrm{~kg} / \mathrm{d}$. However, some studies have also shown that milk yield is not affected by the type of grain or the amount of ruminally degradable starch (Clark and Harshbarger, 1972; Oliveira et al., 1993; Slots et al., 2009).

Most of the knowledge we have so far regarding the effect of feeding system and grains on milk production comes from feeding trials using a small number of cows under controlled conditions. However, the effect of these factors, if any, under commercial conditions over an entire lactation is not known. Although most existing nutritional studies in dairy cows are limited to a few factors, many more factors can be studied simultaneously using large-scale test-day records that include corresponding feed information. Therefore, we combined Quebec's DHIA (Valacta, Sainte-Anne-deBellevue, Quebec, Canada) feed database with their milk-recording data with the objective of finding relationships between feed and milk components in dairy cattle. We hypothesized that milk yield, composition, and lactation curves are affected by both the type of feeding system and grain used as an energy source.

\section{MATERIALS AND METHODS}

More than 15 million test-day records covering a 5-yr period (January 2000 to October 2005) were extracted from the Valacta database. In addition, files containing information on lactation performance, feed composition, feeding systems, and animal characteristics covering the same period were also extracted from the Valacta database. The records obtained from Valacta were converted into SAS files for editing and statistical analyses using SAS software, version 9.3 (SAS Institute, 2011). Several rounds of data editing and file merging were carried out to combine the information on a test-day record basis. The analyses focused on 2 different feeding systems (component and TMR) and on 4 different types of grains fed as energy sources (barley, commercial concentrate, corn grain, and high-moisture corn).

\section{Collection of Feed Information}

The methods for collection of feed information have been described in detail elsewhere (Bilal et al., 2016). Briefly, the test-day records contained information on the feed code (representing feed type), estimate of feed intake for each feed, and percentage chemical composition of each feed. The feed information was collected at the farm by trained technicians from Valacta. All herds were tiestall herds, which facilitated individual feeding. Automatic feeders, which weighed and delivered the various concentrates to each cow at various times during the day, were used in $46 \%$ of the herds. In the remaining herds, the amounts of the various concentrates delivered to each cow were determined from the number and size of scoops of each concentrate delivered by the dairyman to each cow. The amounts of concentrates fed to each cow in herds with automatic feeders were very accurate; in the remaining herds, amounts fed were less accurate but within $0.5 \mathrm{~kg} / \mathrm{d}$. Forages were fed on a group basis, typically consisting of about 15 cows. The amount of forage fed to each cow were estimated by apportioning the amount fed to the group on the basis of the cow's weight, stage of lactation, and production level relative to the group average. In all, 163 different types of feed were represented in the data set, and the average number of different types of feed fed to an individual cow on a test day was 5.7. The chemical composition (DM, CP, ADF, NDF, and RUP) of the various feeds was determined by near-infrared reflectance spectroscopy by Valacta or supplied by the feed supplier/manufacturer; $\mathrm{NE}_{\mathrm{L}}$ was determined for each feed by applying a standard prediction equation to the chemical composition of the feed (NRC, 2001).

\section{Data Editing and File Merging}

The first step of data editing was to identify and remove outliers for feed chemical composition in the testday feed file. For each observation (a single feedstuff for a specific herd-cow-test-day), the values for each of the feed composition variables (\% DM, CP, RUP, NEL, $\mathrm{ADF}, \mathrm{NDF}, \mathrm{NSC}$, fat, $\mathrm{Ca}, \mathrm{P}, \mathrm{Mg}, \mathrm{K}, \mathrm{Na}$, and $\mathrm{Cl}$ ) were tested against minimum and maximum values obtained from the Valacta feed reference library. Observations with 1 or more feed composition variables outside predetermined ranges were deleted from the test-day feed file. Subsequently, for any observations with the same 
animal identification number and the same herd-testperiod identification number were deleted from the testday feed file. One record was deleted if the records were exact duplicates, whereas both records were deleted if records were not exact duplicates (i.e., inconsistent observation between records). The original test-day feed file had 75,948,443 observations from 13,742,016 different test-day records. Based on the above criteria, $6,117,701$ observations were deleted, bringing down the number of observations to $69,830,742$ and the respective number of test-day records to $12,717,170$. The resulting test-day feed file ( 1 record per animal per test-day), which we refer to as the test-day diet summary file, was used as the backbone for merging procedures with the other 10 files used in the analyses (Figure 1). The second step in editing consisted of removing duplicates and observations from herds outside Quebec from the remaining files.

The next step was to merge the various files into one file that combined all the information. The unique herd identification number (hrd_id), animal identification (anm_id), and herd-test day identification (htp_id) were the common variables in the files used for matching purpose. Test-day diet summary records $(12,717,170)$ and test-day production $(15,923,987)$ were merged (by herd, animal, and herd-test-day), resulting in 10,773,568 records. These records were then merged with the animal file $(1,272,868$ observations), giving $10,773,557$ records. The next 5 merges were done with the BW, body condition, breeding, pregnancy, and equipment files. Because these files contained complementary information, records were kept even if they did not have corresponding information for all of these variables. The resulting file, the full information file, had 10,773,557 records and 119 variables.

The data set was edited further before model construction. Only the first 3 parities were included in the analysis and only test-day records up to 360 DIM were retained. For all variables, outliers were removed by eliminating the values that fell 4 standard deviations below or above the mean for breed, parity, and stage of lactation. New continuous, categorical, and binary variables were created to include herd size, season of year, and cows belonging to multiple-breed herds. Test-
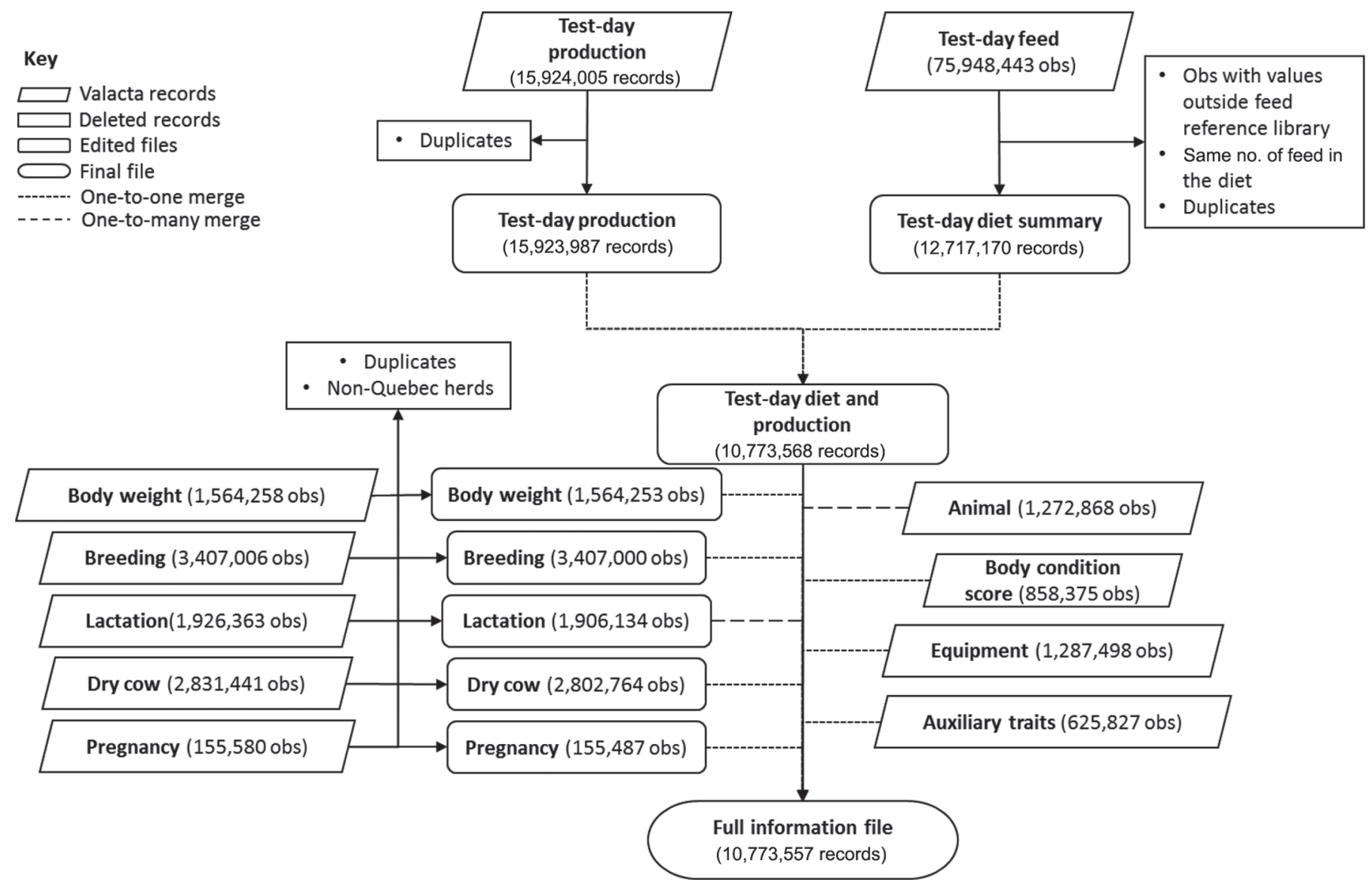

Figure 1. Flow diagram of data editing and file merging step. obs = observations. 
day records were kept if they had 1 type of feeding system per herd. For milk, fat, and protein, at least 5 test-day records per cow per lactation were required, as well as at least 5 animals per herd-year-season of calving. The former restriction was not imposed for lactose or MUN. The reason for this was that, at the time of data collection, lactose and MUN were only measured on 1 of Valacta's mid-infrared milk analyzers. Hence, whether a cow's monthly milk sample was processed by the machine calibrated to record MUN in addition to other milk components was completely random. These conditions were imposed to ensure parameter estimability and to provide an adequate description of the lactation curve of each animal, as random regression modeling was used as described below. The distribution of records by parity, feeding system, and grain diet are shown in Table 1.

\section{Statistical Analyses}

Using the Proc Univariate, Proc Freq, Proc Means, and Proc GPlot procedures of the SAS version 9.3 software (SAS Institute, 2011), descriptive statistics and graphical representations of the data were obtained for each parity, type of feeding system, and type of grain used as an energy source. Records were consolidated in DIM blocks (DIMB) of 15. Graphs of milk and milkcomponent yields by DIMB were produced. These were used to identify possible areas of variation in milk and milk component yields according to type of feeding system used or the type of grain used as an energy source in the cow diets.

Table 2 contains the number of test-day records, number of cows, herds, cows per herd, and tests per cow by traits and parity as well as the mean and standard deviation for each trait. Using the Proc Mixed procedure of SAS 9.3 (SAS Institute, 2011), mixed models for the prediction of milk and milk component yields were developed using a combination of forward and backward stepwise selections. The general form of the mixed model is

$$
\mathrm{Y}=\mathbf{X} \boldsymbol{\beta}+\mathbf{Z} \boldsymbol{\gamma}+\varepsilon
$$

where $\mathrm{Y}$ is the response being modeled (milk or milk components yields), $\mathbf{X}$ is a matrix of nutritional, environmental and animal status variables, and $\boldsymbol{\beta}$ is a vector of the corresponding classification and regression coefficients. These terms represent the fixed portion of the model. The $\mathbf{Z}$ and $\boldsymbol{\gamma}$ account for the random regression effects of herd and cow (and account for the common covariance between measurements on the same observational unit: herd or cow); the random regression
Table 1. Number of records by parity, feeding system, and grain source

\begin{tabular}{lc}
\hline Item & Number of records \\
\hline Parity & \\
1 & 439,126 \\
2 & 275,071 \\
3 & 138,045 \\
Feeding system & 486,605 \\
Component & 365,637 \\
TMR & 43,578 \\
Grain source & 207,265 \\
Barley & 236,593 \\
Commercial concentrate & 364,806 \\
Corn grain & \\
High-moisture corn & \\
\hline
\end{tabular}

used a Wilmink function (Wilmink, 1987). In addition, $\mathbf{Z}$ contains the DIM random regression variables, and $\boldsymbol{\gamma}$ is a vector of their associated random regression coefficients. Cow was nested within a feeding system and herd-year-season of calving. Finally, $\varepsilon$ is a random error term assumed to be normally distributed with a mean of 0 and a constant variance. A total of 22 independent variables were tested for inclusion in the model (Table 3 ); variables were kept in the model if $P<0.01$. Herds were mainly nested within feeding systems and cows were nested within herd-year-season of calving $\times$ feeding system. As herds were mainly nested within feeding system, the degrees of freedom and standard errors for estimation of least squares means and differences between feeding systems are a synthesized combination of the herd-level effect and herd-test-day effects modeled using the Kenward-Roger method in SAS PROC MIXED. Similarly, given that about $20 \%$ of the testday records were from herd-test days with more than 1 available grain source and that grain source was specific to each cow's fed ration per test-day, the degrees of freedom and standard error for estimation of least squares means and comparisons among grain sources are a synthesized combination of the cow-level effect and the individual test-day level effect. Because the study was a retrospective analysis, Scheffé's adjustment was used for all multiple comparisons. $P$-values $<0.05$ were declared as significant.

\section{RESULTS AND DISCUSSION}

The effect of feeding system and grain source were significant for every trait in all parities (Table 4). The feeding system by DIMB was also always significant except for MUN in first- and third-parity cows. The grain source by DIMB interaction was significant for all traits in every lactation, except for milk fat in parity 2 as well as for milk yield, fat, and MUN in parity 3. 
Table 2. Number of test-day records, cows, herds, cows per herd, and tests per cow by trait and parity as well as the mean and standard deviation for each trait

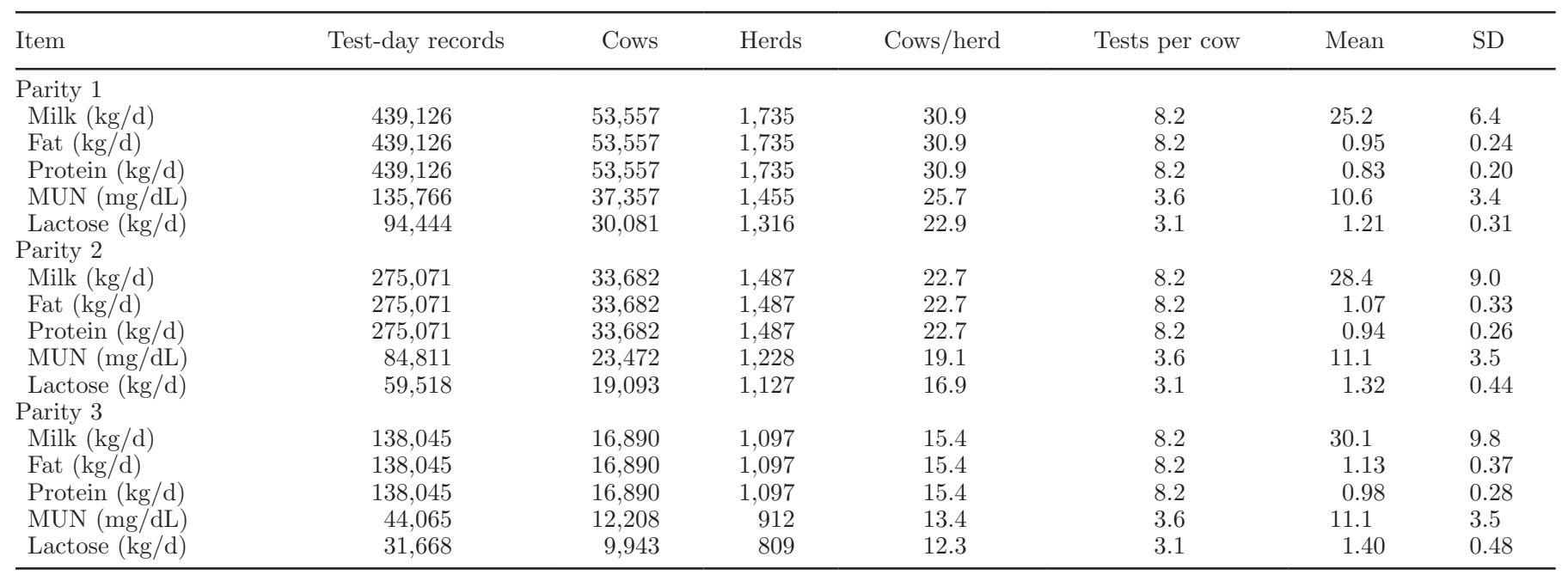

\section{Effect of Feeding Systems}

As shown in Table 5, the TMR feeding system led to an additional production of milk varying from 697 $\mathrm{kg}$ for first-parity cows to $516 \mathrm{~kg}$ for third-parity cows over the complete lactation. These corresponded to 8.6 and $5.3 \%$ higher milk yield in TMR-fed cows during the first and third lactation, respectively. This agrees with previous studies that showed that TMR feeding results in enhanced milk production (Wattiaux et al., 2005; Miglior et al., 2006; Cabrera and Kalantari, 2016). Us-

Table 3. Fixed effect variables used in model construction for milk, fat, protein, and lactose yields and MUN concentration

\begin{tabular}{ll}
\hline $\begin{array}{l}\text { Steps in model } \\
\text { construction }\end{array}$ & Independent variables \\
\hline First step forward & Year-season of calving \\
& Month of test \\
& Energy from grain $(\mathrm{Mcal} / \mathrm{d})$ \\
& DIM block $(\mathrm{DIMB})$ \\
& Type of grain diet \\
& Type of feeding system \\
& Type of grain diet $\times$ DIMB \\
& Type of feeding system $\times$ DIMB \\
& Type of grain diet $\times$ Type of feeding system \\
& DMI $(\mathrm{kg} / \mathrm{d})$ \\
& NE (Mcal $/ \mathrm{d})$ \\
& CP intake $(\mathrm{kg} / \mathrm{d})$ \\
& Forage-to-concentrate ratio \\
& NSC intake $(\mathrm{kg} / \mathrm{d})$ \\
& Fat intake $(\mathrm{kg} / \mathrm{d})$ \\
& NDF intake $(\mathrm{kg} / \mathrm{d})$ \\
& ADF intake $(\mathrm{kg} / \mathrm{d})$ \\
& Forage NDF intake $(\mathrm{kg} / \mathrm{d})$ \\
& RDP intake $(\mathrm{kg} / \mathrm{d})$ \\
& Milk sampling routine \\
& Pregnancy status \\
& Age at calving $(\mathrm{d})$ \\
\hline
\end{tabular}

ing the fixed effect of feeding systems by DIMB interaction to analyze the effect of feeding system over the entire lactation, we observed that milk yield curves in all parities, and for both feeding systems, were similar to previously reported milk yield curves (Keown and Everett, 1986; Stanton et al., 1992). Daily milk yield displayed a rapid increase in the first days of the lactations to peak on DIMB 3 (between 31 and $45 \mathrm{~d}$ ), followed by a continuous decline over the remainder of the lactation. However, greater milk yield peaks were observed for TMR-fed cows compared with componentfed cows. Although yield differences decreased along the entire lactation curves for TMR- and component-fed cows, the decrease rate was similar, and higher yields were maintained until the end of the lactations. For example, significantly greater milk yields by DIMB for TMR-fed cows are seen from peak milk yield until 135 DIM (i.e., DIMB = 9) in third-parity cows (Figure 2). Similar trends were observed in first- and second-parity Holsteins, although differences were only numerical. This finding agrees with observations made by Sung and Kim (2004), where in early and mid-lactation cows fed with a TMR feeding system showed greater milk yield when compared with cows fed with a component feeding system. Furthermore, numerous studies (Kolver and Muller, 1998; White et al., 2001; Bargo et al., 2002) have shown that TMR-fed cows have a greater milk yield than pasture-fed cows, supplemented or not, and that the increase in milk yield is often associated with higher DMI or energy intake or both. However, in our study, the effect of DMI, energy intake, and several other dietary components (all $P<0.01$ ) were included in all the prediction models constructed. We interpreted the latter to mean that the differences observed in milk 
Table 4. Significance level of feeding system, grain source, and their interaction with DIM block by trait and parity

\begin{tabular}{|c|c|c|c|c|c|}
\hline Trait & Parity & $\mathrm{FS}^{1}$ & $\mathrm{FS} \times \mathrm{DIMB}^{2}$ & $\mathrm{GS}^{3}$ & $\mathrm{GS} \times \mathrm{DIMB}^{4}$ \\
\hline \multirow[t]{3}{*}{ Milk (kg/d) } & 1 & $<0.0001$ & $<0.0001$ & $<0.0001$ & 0.0001 \\
\hline & 2 & $<0.0001$ & $<0.0001$ & $<0.0001$ & 0.0003 \\
\hline & 3 & $<0.0001$ & $<0.0001$ & $<0.0001$ & 0.2961 \\
\hline \multirow[t]{3}{*}{ Fat $(\mathrm{kg} / \mathrm{d})$} & 1 & $<0.0001$ & $<0.0001$ & $<0.0001$ & $<0.0001$ \\
\hline & 2 & $<0.0001$ & $<0.0001$ & $<0.0001$ & 0.2701 \\
\hline & 3 & $<0.0001$ & $<0.0001$ & $<0.0001$ & 0.2847 \\
\hline \multirow[t]{3}{*}{ Protein $(\mathrm{kg} / \mathrm{d})$} & 1 & $<0.0001$ & $<0.0001$ & $<0.0001$ & 0.0034 \\
\hline & 2 & $<0.0001$ & $<0.0001$ & $<0.0001$ & 0.0081 \\
\hline & 3 & $<0.0001$ & $<0.0001$ & $<0.0001$ & $<0.0001$ \\
\hline \multirow[t]{3}{*}{ Lactose $(\mathrm{kg} / \mathrm{d})$} & 1 & $<0.0001$ & $<0.0001$ & $<0.0001$ & 0.0213 \\
\hline & 2 & $<0.0001$ & $<0.0001$ & $<0.0001$ & 0.0002 \\
\hline & 3 & $<0.0001$ & $<0.0001$ & $<0.0001$ & 0.0161 \\
\hline \multirow{3}{*}{ MUN (mg/dL) } & 1 & $<0.0001$ & 0.1317 & $<0.0001$ & $<0.0001$ \\
\hline & 2 & $<0.0001$ & 0.0317 & $<0.0001$ & 0.0362 \\
\hline & 3 & 0.0086 & 0.0875 & $<0.0001$ & 0.0521 \\
\hline
\end{tabular}

yield for the feeding system by DIMB interaction were not due to differences in nutrient intake, as this was accounted for in the models.

One explanation for these greater milk yields in feeding system by DIMB interaction and higher peak milk yields in TMR-fed cows relate to the concept proposed by Coppock (1977), that each bite of TMR consumed by the cow is a uniform and, in theory, nutritionally complete diet. On the other hand, component-fed cows receive different feeds in a sequence and, consequently, are more likely to express preferences for some feeds over others. By consuming a complete diet in each bite, TMR-fed cows tend to have less digestive problems, fewer metabolic problems, and a more stable environment in their rumen (Coppock et al., 1981). So, for feeding systems with the same components, cows receiving the diet prepared by a TMR system would be expected to make better use of the available nutrients than the cows receiving the diet component separately. The higher daily milk yield in early-lactation cows fed a TMR compared with component fed diets may be related to better use of nutrients and greater amounts of substrates available to the mammary gland for the synthesis and secretion of milk and milk components.

In addition to milk yield, the TMR systems also resulted in greater production of fat, protein, and lactose, ranging from 4.7 to $10.8 \%$ (Table 5 ). The largest differences were observed in first-parity cows, with smaller differences in second- and third-parity cows. Milk component (i.e., fat, protein, and lactose) yields

Table 5. Least squares means and differences between feeding systems over a complete lactation

\begin{tabular}{|c|c|c|c|c|c|c|c|c|c|c|c|}
\hline Trait & Parity & \multicolumn{3}{|c|}{ Component } & \multicolumn{3}{|c|}{ TMR } & \multicolumn{3}{|c|}{ Difference } & $P$-value \\
\hline \multirow[t]{2}{*}{ Milk (kg/d) } & 1 & 2,206 & 8,149 & 31 & 1,854 & 8,846 & 46 & 1,805 & 697 & 54 & $<0.0001$ \\
\hline & 3 & 2,228 & 9,781 & 56 & 1,569 & 10,297 & 72 & 1,159 & 516 & 82 & $<0.0001$ \\
\hline \multirow[t]{2}{*}{ Fat (kg/d) } & 1 & 2,396 & 317 & 1.2 & 1,901 & 351 & 1.9 & 1,808 & 34 & 2.2 & $<0.0001$ \\
\hline & 2 & 2,640 & 356 & 1.7 & 1,498 & 386 & 2.5 & 1,940 & 30 & 2.8 & $<0.0001$ \\
\hline \multirow{2}{*}{ Protein $(\mathrm{kg} / \mathrm{d})$} & 2 & 2,344 & 308 & 1.4 & 2,180 & 337 & 2.1 & 1,832 & 30 & 2.4 & $<0.0001$ \\
\hline & 3 & 2,342 & 323 & 1.8 & 2,077 & 347 & 2.5 & 1,489 & 24 & 2.8 & $<0.0001$ \\
\hline \multirow[t]{3}{*}{ Lactose $(\mathrm{kg} / \mathrm{d})$} & 1 & 2,873 & 400 & 2 & 1,779 & 432 & 2.6 & 1,308 & 33 & 2.9 & $<0.0001$ \\
\hline & 2 & 2,642 & 441 & 2.6 & 1,620 & 470 & 3.3 & 1,074 & 29 & 3.7 & $<0.0001$ \\
\hline & 3 & 2,299 & 460 & 3.6 & 1,467 & 481 & 4.2 & 766 & 22 & 4.5 & $<0.0001$ \\
\hline \multirow[t]{2}{*}{ MUN (mg/dL) } & 1 & 3,417 & 11.1 & 0.1 & 2,000 & 10.6 & 0.1 & 1,435 & -0.6 & 0.1 & $<0.0001$ \\
\hline & 2 & 2,889 & 11.7 & 0.1 & 1,805 & 10.9 & 0.1 & 1,221 & -0.8 & 0.1 & $<0.0001$ \\
\hline
\end{tabular}


are directly related to milk yields, with higher daily milk yields normally leading to higher milk component yields. However, milk fat and protein lactation curves for TMR-fed cows showed different patterns than for component-fed cows. In contrast to the continuous decrease in the yield of these components over the entire lactation observed in component-fed cows, cows fed TMR reached a peak for milk fat (Figure 3 ) and protein yield (Figure 4) around 45 DIM and then decreased over the rest of lactation.

Milk fat yield lactation curves observed in our study resembled those of prior studies (Keown and Everett, 1986; Stanton et al., 1992). However, differences were found with the predictive models of daily milk fat yield, in which both the feeding system and feeding system by DIMB fixed effects were significant and fat yields were greater with TMR systems. For example, in thirdparity cows, significantly higher daily milk fat yields for TMR-fed cows were observed from DIMB 2 to 10 (i.e., between 16 and 150 DIM; Figure 3). Moreover, differences in the shape of the lactation curves between the feeding systems were evident. Milk fat yields decreased continuously over the entire lactation in the case of component-fed cows, whereas the decrease started only after the third DIMB (i.e., after 45 DIM) for TMRfed animals. This suggests a better use of available substrates for the mammary gland, leading to a better efficiency to produce fat in the TMR-feeding system.
Milk protein yield was also different between feeding systems. The fixed effect of feeding system by DIMB interaction on daily milk protein yield was statistically significant for all parities. Higher daily milk protein yields by DIMB were seen for TMR-fed cows from DIMB 3 to 15 (i.e., from 31 to 225 DIM) in third-parity cows when compared with those fed with components feeding systems (Figure 4). Similar patterns were observed in the other parities. The milk protein yield curves for TMRand component-fed cows displayed a different pattern. The TMR-fed cows' milk protein curve resembled the milk yield curve. Milk protein yields increased in early lactation to a maximum around 60 DIM (i.e., DIMB 4) and then decreased over the rest of the lactation, as opposed to a continuous decrease over the entire lactation in component-fed cows. Differences were significant for almost the whole curve for first parity, which was not the case for parities 2 and 3 . Milk protein production is highly influenced by AA availability to the mammary gland (Doepel et al., 2004). We propose that a TMR feeding system supports greater protein synthetic and secretory activity during early lactation and a better persistency during the remaining lactation compared with component feeding, particularly in first-lactation cows.

With respect to daily milk lactose yield, the fixed effect of feeding system by DIMB was significant for all parities. Higher daily milk lactose yields were observed

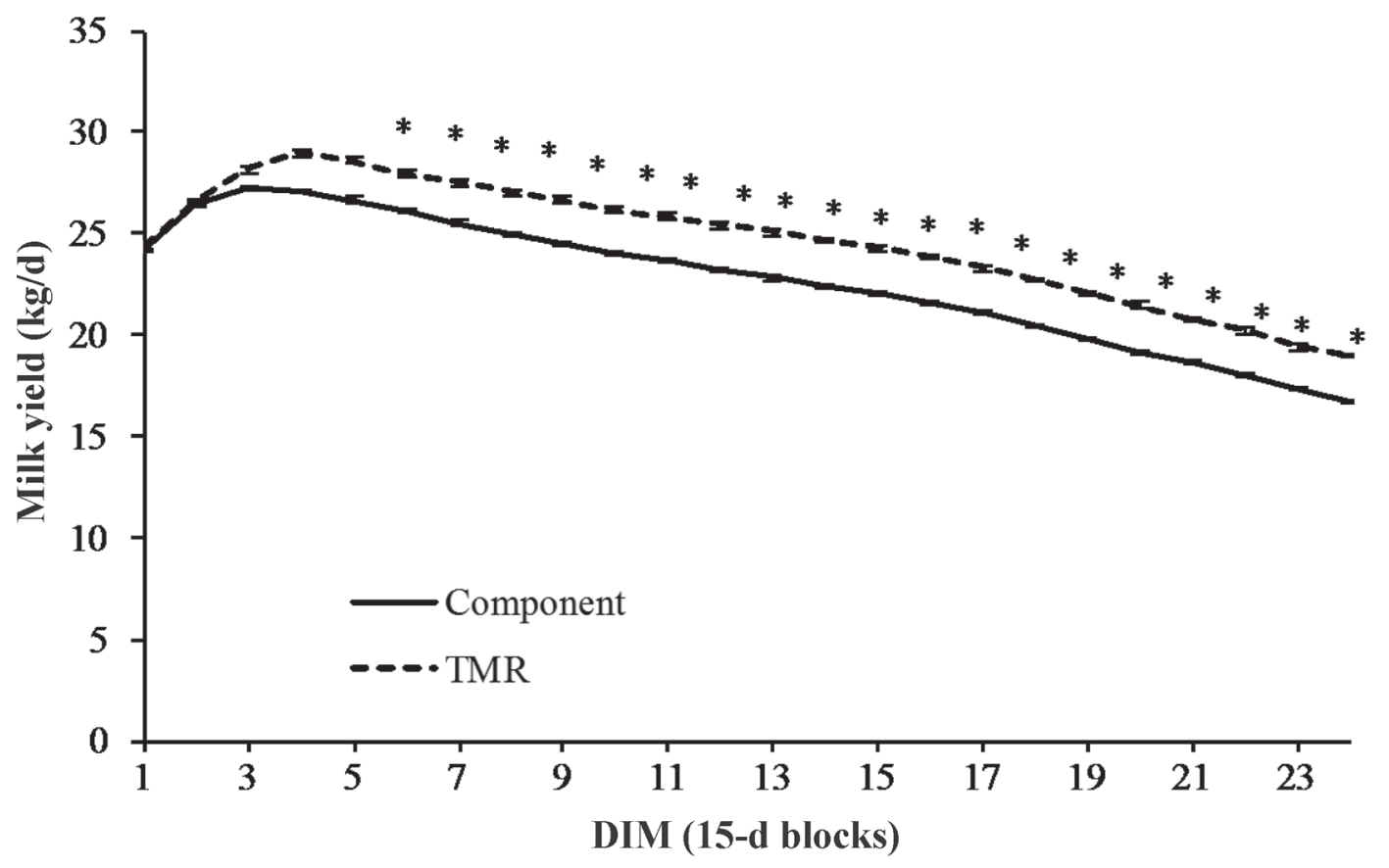

Figure 2. Least squares means of daily milk yield per DIM block according to feeding systems in third-parity Holstein cows. ${ }^{*} P<0.05$, component vs. TMR. The df for the difference between component and TMR ranged between 2,026 and 2,840 . The error bars represent \pm SE. 


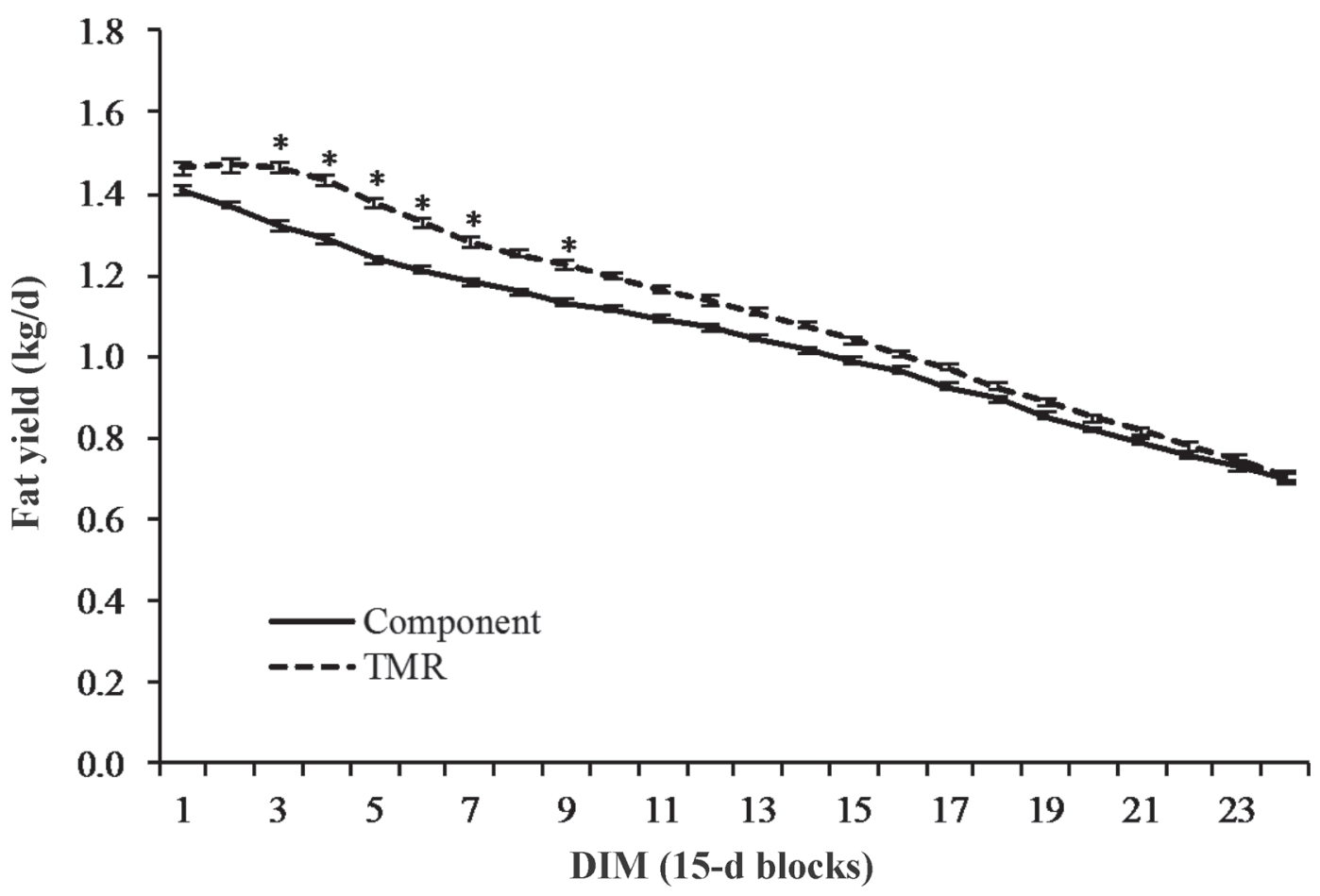

Figure 3. Least squares means of daily milk fat yield per DIM block according to feeding systems in third-parity Holstein cows. $* P<0.05$, component vs. TMR. The df for the difference between component and TMR ranged between 1,675 and 4,855. The error bars represent \pm SE.

in early lactation for TMR-fed cows compared with component-fed cows in all 3 parities. The TMR-fed cows had higher daily lactose yields than component fed-cows, as illustrated in Figure 5. Differences in daily milk lactose yields by DIMB between feeding systems were significant over almost the whole lactation curve for first-parity cows, whereas differences were significant only from DIMB 3 to 7 and 4 to 5 in parity 2 and 3 , respectively.

The MUN concentration was lower by as much as $6.6 \%$ (i.e., from 11.7 to $10.9 \mathrm{mg} / \mathrm{dL}$ ) under the TMR system for second-parity cows (Table 5); we found no differences on specific DIMB. The MUN lactation curves resembled that of previous studies (Wattiaux et al., 2005; Miglior et al., 2006), with a decrease in MUN levels to a minimum in between 31 and 45 DIM and a gradual constant increase over the rest of lactation. Therefore, in addition to greater yields of milk and milk components, TMR-fed cows had lower MUN levels, which suggest a better utilization of diet CP; presumably, this could be due to better feed efficiency and less waste of protein with a consequent reduction in urinary-urea excretion. These factors would all contribute to a better feed conversion ratio and, under certain feeding conditions, a better return over feed costs.

\section{Effect of Grain Sources}

The effect of grain sources was significant for all traits and parities (Table 4). Least squares means and pairwise differences for grain sources are in Table 6 and 7 , respectively. In general, milk production increased numerically from barley to concentrates to corn grain to high-moisture corn. Milk yield differed in barleyand concentrate-fed cows only for first-parity cows, but corn-fed cows produced significantly more milk than barley-fed cows in all parities (Table 7). High-moisture corn led to higher milk production compared with concentrates for all parities and compared with corn grain in first and second parities. Although the grain source by DIMB interaction effect was significant in predictive models of daily milk yield in first- and secondparity cows, none of the analyses differed among diets by DIMB. These results agreed with prior studies; for example, higher milk yields for cows fed corn grain compared with cows fed barley (McCarthy et al., 1989; Casper et al., 1990; Ferraretto et al., 2013) as well as cows fed high-moisture corn compared with cows fed dry corn (Wilkerson et al., 1997) have been reported. In a recent meta-analysis of cereal grain type and corn grain-harvesting methods on milk composition, Fer- 

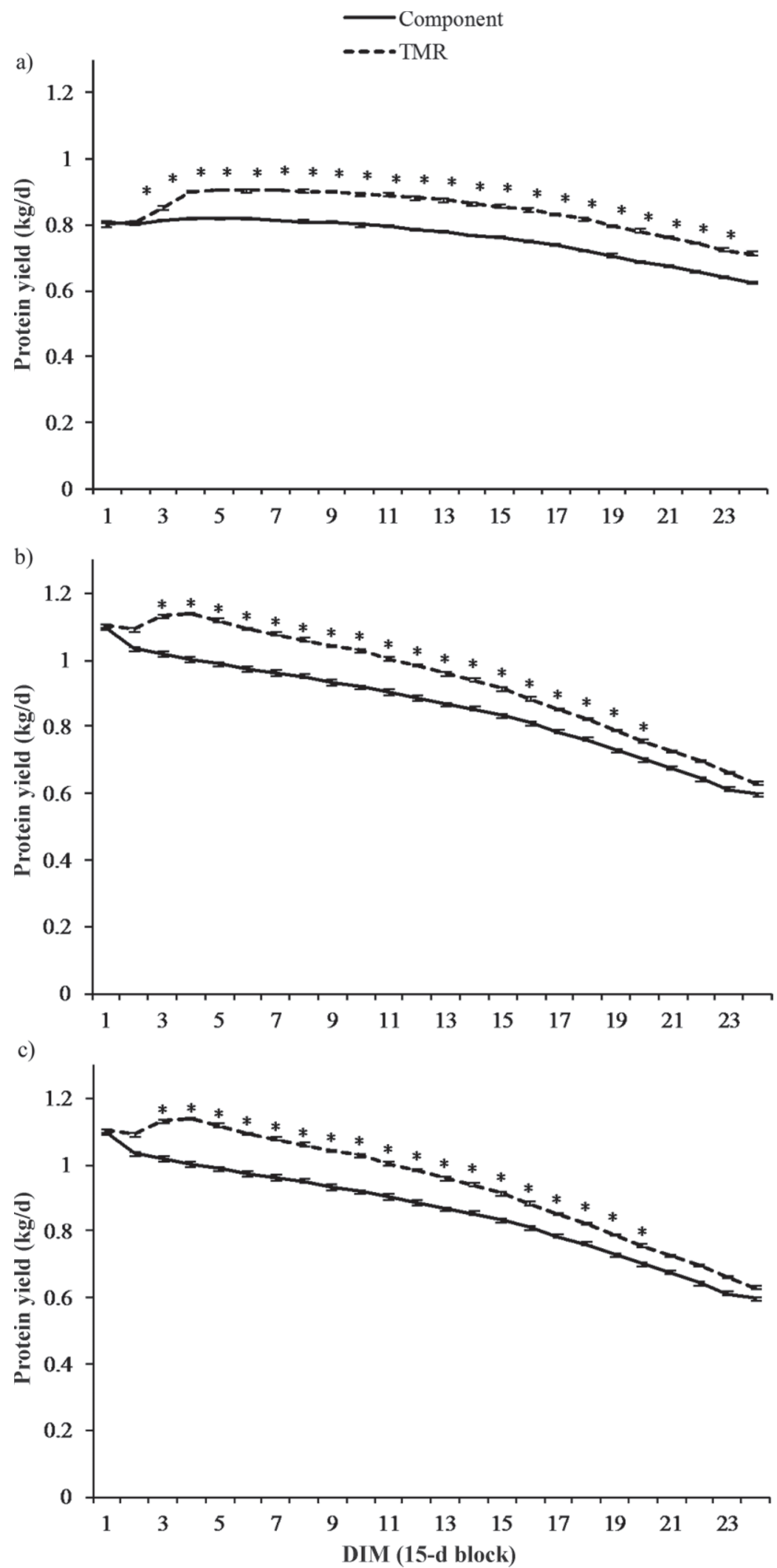

Figure 4. Least squares means of daily milk protein per DIM block according to feeding systems in (a) first-, (b) second-, and (c) third-parity Holstein cows. ${ }^{*} P<0.05$, component vs. TMR. The df for the difference between component and TMR ranged between 1,752 and 3,690 . The error bars represent $\pm \mathrm{SE}$. 


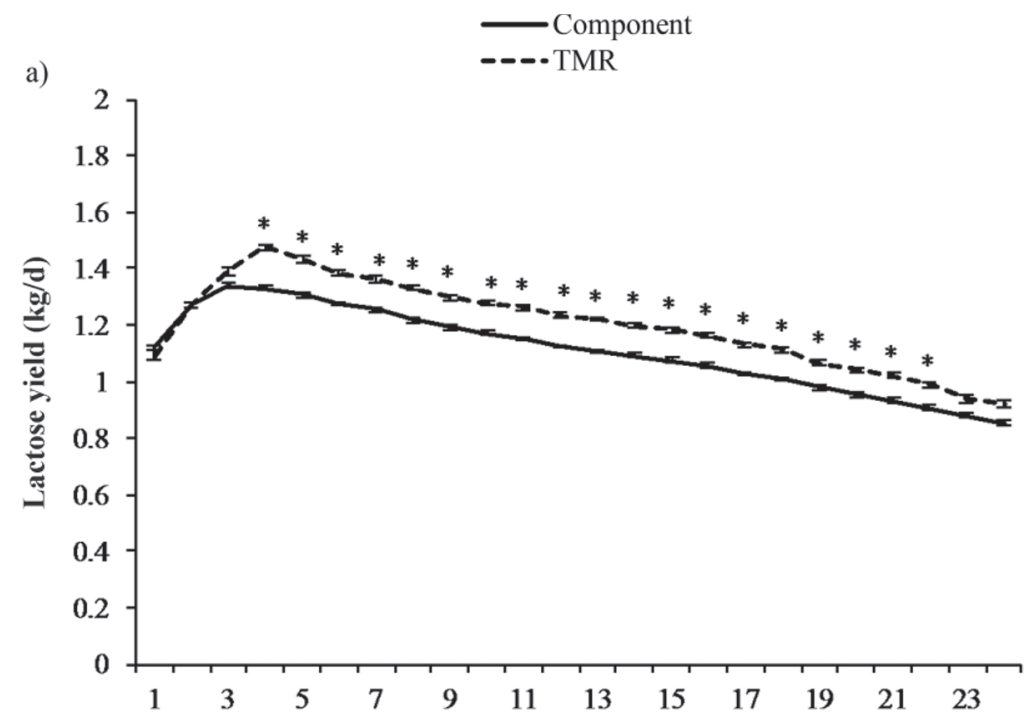

b)
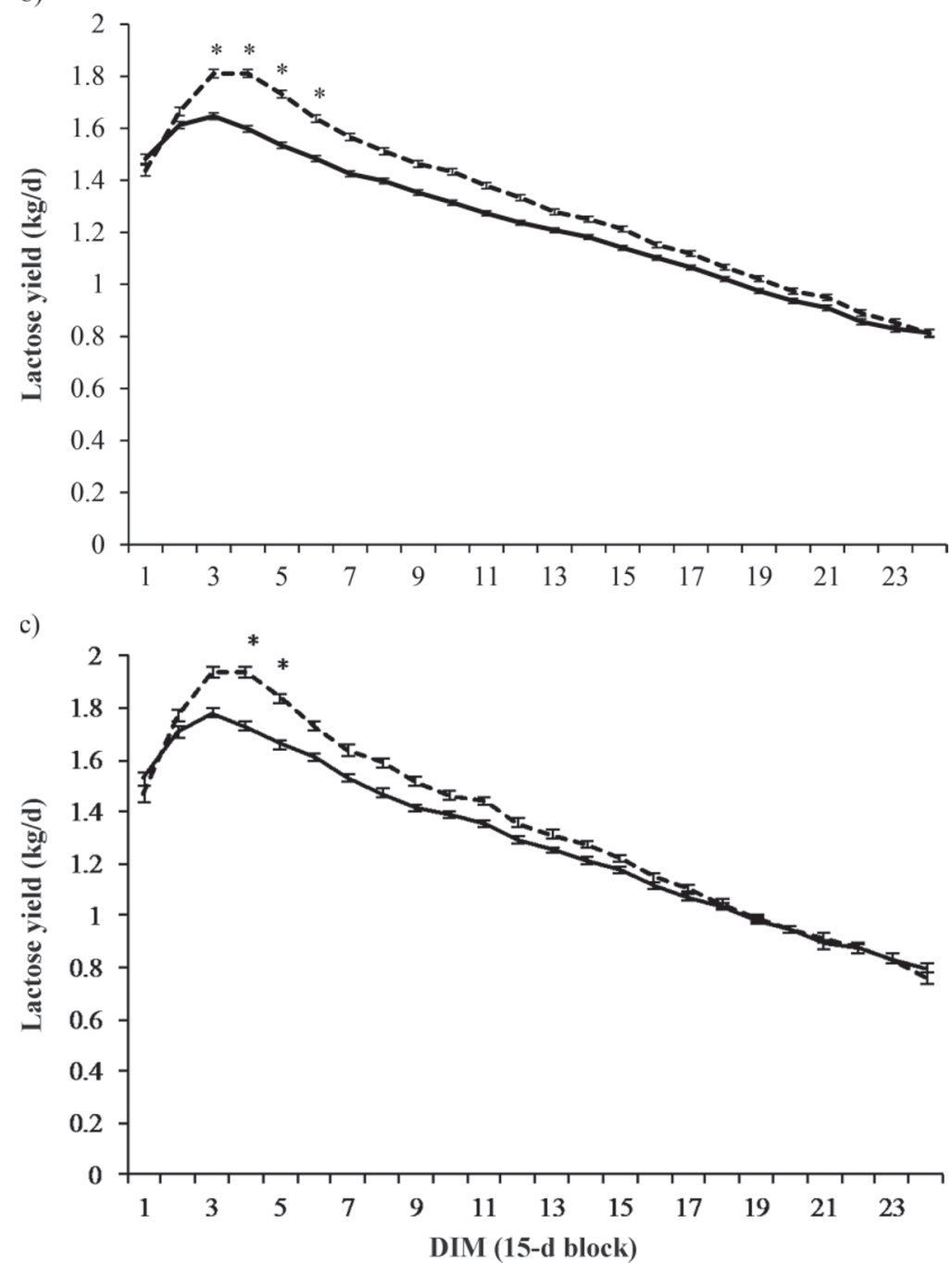

Figure 5. Least squares means of daily milk lactose yield per DIM block according to feeding systems in (a) first-, (b) second-, and (c) thirdparity Holstein cows. ${ }^{*} P<0.05$, component vs. TMR. The df for the difference between component and TMR ranged between 674 and 4,930 . The error bars represent $\pm \mathrm{SE}$. 
raretto et al. (2013) showed milk fat concentration and $4 \% \mathrm{FCM}$ was higher in cows fed dry corn grain compared with high-moisture corn, but milk yield and protein concentration did not differ. However, our results contrast with other studies that have shown that milk yield was not affected by the type of grain or the amount of ruminally degraded starch (Clark and Harshbarger, 1972; Oliveira et al., 1993).

Although the grain sources by DIMB interaction was significant for predictions of milk yield, milk component yields, and MUN concentration, no differences were found on specific DIMB among the 4 different grain sources by DIMB. However, similar results were observed with greater milk and milk fat and protein yields and lower MUN concentration for cows receiving corn grain or high-moisture in comparison to cows receiving barley or commercial concentrate. Grain source had a significant effect on the prediction of fat production for all parities (Table 4), but differences between the sources of grain were not always significant (Table 7). Barley- and corn-based diets generally led to greater production of fat than concentrates, and no differences were found between corn grain and high-moisture corn. The grain source by DIMB interaction was significant only for first-parity cows.

The type of grain had a significant effect in the prediction of milk protein yield in all parities. A precise pattern of differences among diets was difficult to establish because the differences varies from parity to parity in most pairwise comparisons. However, corn-based diets tended to lead to greater production of protein than the other 2 types of diets. The grain source by DIMB effect was significant in predictive models of daily milk protein yield in all 3 parities. However, none of the analyses yielded significant differences among diets by DIMB. Tendencies for higher peak milk protein yields were observed when cows were fed high-moisture corn compared with the 3 other types of grain. This agrees with Lykos et al. (1997), in which significant increases in milk protein yields $(130 \mathrm{~g} / \mathrm{d})$ were obtained by increasing the rate of NSC digestion from 6 to $7.9 \% / \mathrm{h}$. Higher milk protein yields throughout the lactation were observed when cows were fed high-moisture corn or corn grain compared with those receiving barley or commercial concentrate. This suggests that the highenergy density and rapid rate of ruminal degradation of starch in corn-based diets led to greater synthesis of milk proteins.

The effect of the source of grain was also significant for lactose yield. Except for second-parity cows, differences were observed between both barley and concentrates when compared with corn-based diets. The 2 types of corn sources also led to differences for the same parities. Substantial disparities were also found

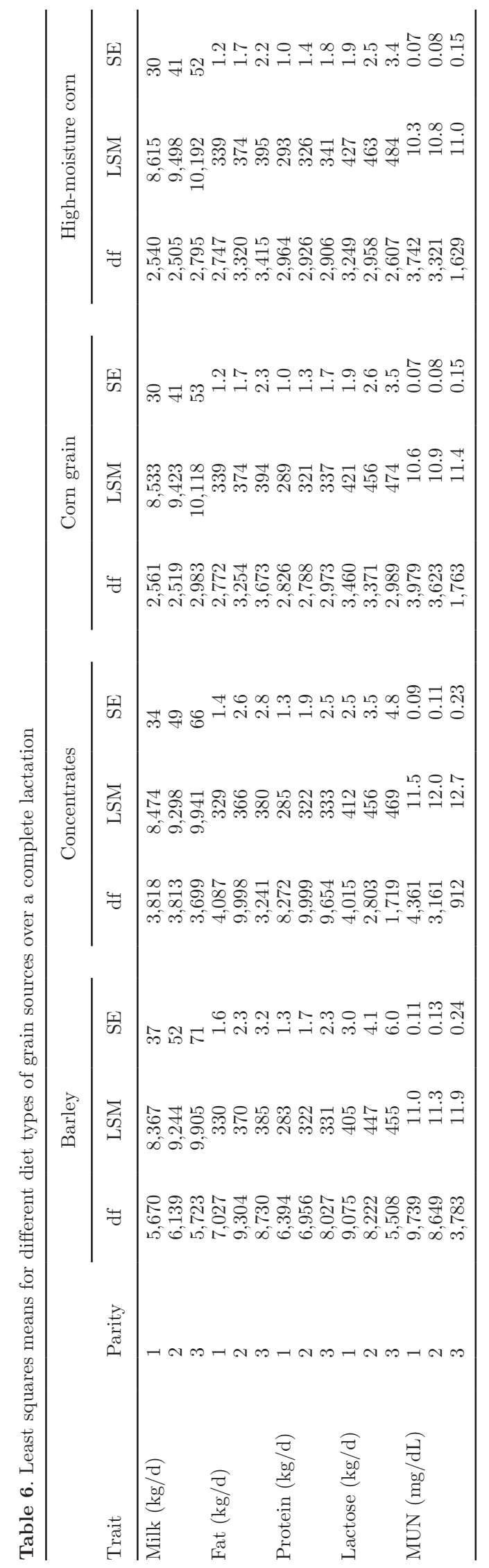



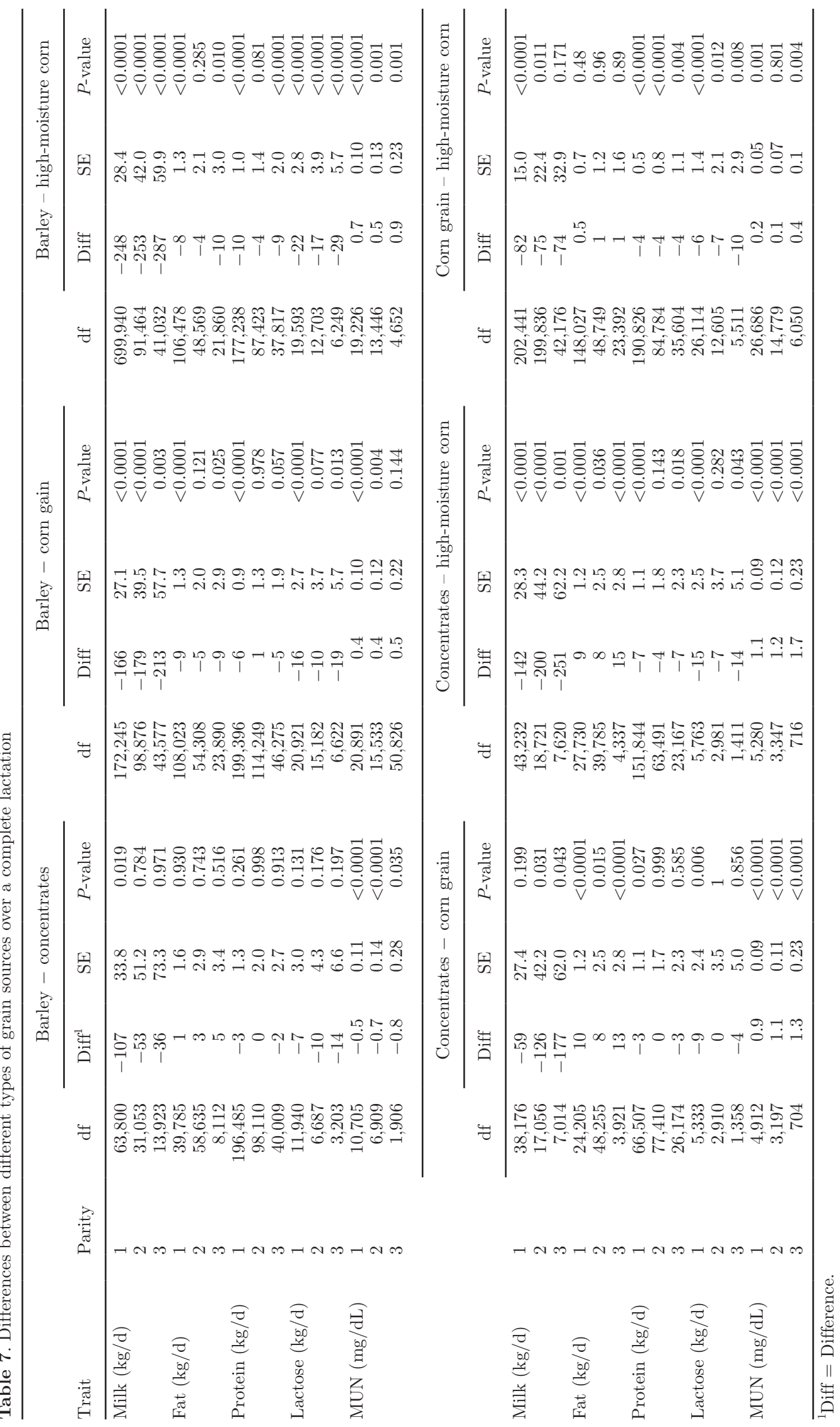
in other pairwise combinations (e.g., concentrates and grain source by DIMB interaction were significant only for second-parity cows). Knowing that milk lactose concentration is closely related to milk yield, greater differences in milk lactose yield (according to the grain source) might have been expected.

The source of grain in the diet was significant in predicting MUN. A tendency for lower MUN was noted for cows receiving corn grain and high-moisture corn in contrast to cows receiving barley or commercial concentrate, which supports other studies. Burkholder et al. (2004) reported lower MUN concentrations when cows were fed steam-flaked corn versus dry ground corn. Concentrates led to the highest concentrations of MUN, which likely had a greater CP content, followed by barley, corn grain, and high-moisture corn. The largest observed difference was between concentrates and high-moisture corn for cows in their third parity, with MUN of 12.7 and $11.0 \mathrm{mg} / \mathrm{dL}$. The grain source by DIMB effect was only significant in first- and secondparity cows. Similarly, lower MUN concentrations were observed in cows fed dry ground corn compared with cows fed a mix of barley and molasses (Gehman et al., 2006) or a mix of barley and corn (Foley et al., 2006). This would seem to indicate that a lower MUN represents better utilization of the $\mathrm{CP}$ fraction of the diet in cows fed high-moisture corn or corn grain compared with cows fed barley or commercial concentrate. This effect may lead to a reduction in excretion, thereby helping to allay some environmental concerns. Possible explanations regarding the effect of grain sources by DIMB are not obvious. Not only did none of the analyses yield significant differences among the different grain source by DIMB but, when the effect was found significant in predictive models, it was often only for first- or second-parity groups. Therefore, the lack of consistency in the results makes it hard to recommend a grain source that could improve milk or milk component yields or both.

\section{Limitation of this Study}

This study was designed by limiting the number of factors to those considered to have a potential influence on the variables of interest. For example, we included only Holstein cows in first to third parity that were housed in tiestall barns. However, the results of the study may have been confounded by nutritional and management practices associated with feeding systems and grain sources for which data were not available, and therefore could not be controlled for, such as frequency of feed delivery, milking frequency, and genetic potential. In addition, information on the feedstuff composition of the concentrates was not available. It is also possible that the effect of feeding system could be confounded by differences in diet composition (e.g., that the use of corn silage vs. grass silage vs. alfalfa silage differed in TMR-fed compared with componentfed herds). Therefore, additional studies that account for these potential sources of variation are warranted.

\section{CONCLUSIONS}

Using data from commercial herds in Quebec over a 5-yr period, we showed that cows fed TMR had greater yields of milk, fat, protein, and lactose as well as lower MUN concentrations than component-fed cows at all parities. In general, greater milk, fat, and protein yields as well as lower MUN concentrations were observed in cows fed corn grain or high-moisture corn compared with barley or commercial concentrate, but differences among parities were observed for some comparisons. The effect of feeding system differed among stages of lactation, as measured by DIMB, in models of milk and components yields for all parities, but only for secondlactation cows for MUN concentration. The study confirms results from feeding trials, that TMR and corn-based diets are associated with greater production of milk and higher yield of milk components.

\section{ACKNOWLEDGMENTS}

This research was funded by Novalait, the Québec Ministry for Agriculture, Fisheries and Food, the Québec Technological Research Fund and Agriculture and Agri-Food Canada. Computing facilities were provided through the Canadian Foundation for Innovation.

\section{REFERENCES}

Bargo, F., L. D. Muller, J. E. Delahoy, and T. W. Cassidy. 2002. Performance of high producing dairy cows with three different feeding systems combining pasture and total mixed rations. J. Dairy Sci. 85:2948-2963.

Bilal, G., R. Cue, and J. Hayes. 2016. Genetic and phenotypic associations of type traits and body condition score with dry matter intake, milk yield and number of breedings in first lactation Canadian Holstein cows. Can. J. Anim. Sci. 96:434-447.

Bittante, G., C. Cipolat-Gotet, F. Malchiodi, E. Sturaro, F. Tagliapietra, S. Schiavon, and A. Cecchinato. 2015. Effect of dairy farming system, herd, season, parity, and days in milk on modeling of the coagulation, curd firming, and syneresis of bovine milk. J. Dairy Sci. 98:2759-2774.

Burkholder, K. M., A. D. Guyton, J. M. McKinney, and K. F. Knowlton. 2004. The effect of steam flaked or dry ground corn and supplemental phytic acid on nitrogen partitioning in lactating cows and ammonia emission from manure. J. Dairy Sci. 87:2546-2553.

Cabrera, V. E., and A. S. Kalantari. 2016. Economics of production efficiency: Nutritional grouping of the lactating cow. J. Dairy Sci. 99:825-841.

Casper, D. P., D. J. Schingoethe, and W. A. Eisenbeisz. 1990. Response of early lactation dairy cows fed diets varying in source of nonstructural carbohydrate and crude protein. J. Dairy Sci. 73:1039-1050. 
Clark, J. H., and K. E. Harshbarger. 1972. High-moisture corn versus dry corn in combination with either corn sillage of hay for lactation cows. J. Dairy Sci. 55:1474-1480.

Coppock, C. E. 1977. Feeding methods and grouping systems. J. Dairy Sci. 60:1327-1336.

Coppock, C. E., D. L. Bath, and B. J. Harris. 1981. From feeding to feeding systems. J. Dairy Sci. 64:1230-1249.

Doepel, L., D. Pacheco, J. J. Kennelly, M. D. Hanigan, I. F. Lopez, and H. Lapierre. 2004. Milk protein synthesis as a function of amino acid supply. J. Dairy Sci. 87:1279-1297.

Ferraretto, L. F., P. M. Crump, and R. D. Shaver. 2013. Effect of cereal grain type and corn grain harvesting and processing methods on intake, digestion, and milk production by dairy cows through a meta-analysis. J. Dairy Sci. 96:533-550.

Ferris, C. P., J. P. Frost, R. C. Binnie, and D. C. Patterson. 2006 Dairy cow performance and labour inputs associated with two silage feeding systems. Grass Forage Sci. 61:304-314.

Foley, A. E., A. N. Hristov, A. Melgar, J. K. Ropp, R. P. Etter, S. Zaman, C. W. Hunt, K. Huber, and W. J. Price. 2006. Effect of barley and its amylopectin content on ruminal fermentation and nitrogen utilization in lactating dairy cows. J. Dairy Sci. 89:43214335.

Gehman, A. M., J. A. Bertrand, T. C. Jenkins, and B. W. Pinkerton. 2006. The effect of carbohydrate source on nitrogen capture in dairy cows on pasture. J. Dairy Sci. 89:2659-2667.

Hutjens, M. F. 1996. Practical approaches to feeding the high producing cow. Anim. Feed Sci. Technol. 59:199-206.

Kargar, S., G. R. Ghorbani, M. Khorvash, A. Sadeghi-Sefidmazgi, and D. J. Schingoethe. 2014. Reciprocal combinations of barley and corn grains in oil-supplemented diets: Feeding behavior and milk yield of lactating cows. J. Dairy Sci. 97:7001-7011.

Kennelly, J. J. 1996. Producing milk with 2,5\% fat-The biology and health implication for dairy cows. Anim. Feed Sci. Technol. 60:161-180.

Kennelly, J. J., and D. R. Glimm. 1998. The biological potential to alter the composition of milk. Can. J. Anim. Sci. 78:23-56.

Keown, J. F., and R. W. Everett. 1986. Effect of days carried calf, days dry, and weight of first calf heifers on yield. J. Dairy Sci. 69:1891-1896.

Kolver, E. S., and L. D. Muller. 1998. Performance and nutrient intake of high producing Holstein cows consuming pasture or a total mixed ration. J. Dairy Sci. 81:1403-1411.

Larkin, J. C., and O. T. Fosgate. 1970. Comparisons of two different systems of feeding dairy cows for three consecutive lactations. J. Dairy Sci. 53:561-565.

Lykos, T., G. A. Varga, and D. Casper. 1997. Varying degradation rates of total nonstructural carbohydrates: Effects on ruminal fermentation, blood metabolites, and milk production and composition in high producing Holstein cows. J. Dairy Sci. 80:3341-3355.
Macleod, G. K., P. E. Colucci, A. D. Moore, D. G. Grieve, and N. Lewis. 1994. The effects of feeding frequency of concentrates and feeding sequence of hay on eating behavior, ruminal environement and milk production in dairy cows. Can. J. Anim. Sci. 1:103-113.

McCarthy, R. D. Jr., T. H. Klusmeyer, J. L. Vicini, J. H. Clark, and D. R. Nelson. 1989. Effects of source of protein and carbohydrate on ruminal fermentation and passage of nutrients to the small intestine of lactating cows. J. Dairy Sci. 72:2002-2016.

Miglior, F., A. Sewalem, J. Jamrozik, D. M. Lefebvre, and R. K. Moore. 2006. Analysis of milk urea nitrogen and lactose and their effect on longevity in Canadian dairy cattle. J. Dairy Sci. 89:4886-4894.

National Research Council. 2001. Nutrient Requirements of Dairy Cattle. 7th rev. ed. Natl. Acad. Press, Washington, DC.

Nocek, J. E. 1992. Feeding sequence and strategy effects on ruminal environment and production performance in first lactation cows. J. Dairy Sci. 75:3100-3108.

Oliveira, J. S., J. T. Huber, D. Ben-Ghedalia, R. S. Swingle, C. B. Theurer, and M. Pessarakli. 1993. Influence of sorghum grain processing on performance of lactating dairy cows. J. Dairy Sci. $76: 575-581$

SAS Institute. 2011. SAS/STAT 9.3 User's Guide. No. Cary, NC. SAS Institute Inc., Cary, NC.

Slots, T., G. Butler, C. Leifert, T. Kristensen, L. H. Skibsted, and J. H. Nielsen. 2009. Potentials to differentiate milk composition by different feeding strategies. J. Dairy Sci. 92:2057-2066.

Stanton, T. L., L. R. Jones, R. W. Everett, and S. D. Kachman. 1992. Estimating milk, fat, and protein lactation curves with a test day model. J. Dairy Sci. 75:1691-1700.

Sung, H. G., and D. K. Kim. 2004. Effect of herd-mix feeding system formulated by energy requirement levels on the performance of lactating cows. J. Anim. Sci. Technol. 46:773-782.

Walker, G. P., F. R. Dunshea, and P. T. Doyle. 2004. Effects of nutrition and management on the production and composition of milk fat and protein: A review. Aust. J. Agric. Res. 55:1009-1028.

Wattiaux, M. A., E. V. Nordheim, and P. Crump. 2005. Statistical evaluation of factors and interactions affecting dairy herd improvement milk urea nitrogen in commercial Midwest dairy herds. J. Dairy Sci. 88:3020-3035.

White, S. L., J. A. Bertrand, M. R. Wade, S. P. Washburn, J. T. Green Jr., and T. C. Jenkins. 2001. Comparison of fatty acid content of milk from Jersey and Holstein cows consuming pasture or a total mixed ration. J. Dairy Sci. 84:2295-2301.

Wilkerson, V. A., B. P. Glen, and K. R. McLeod. 1997. Energy and nitrogen balance in lactating cows fed diets containing dry or high moisture corn in either rolled or ground form. J. Dairy Sci. 80:2487-2496.

Wilmink, J. B. M. 1987. Adjustment of test-day milk, fat and protein yield for age, season and stage of lactation. Livest. Prod. Sci. $16: 335-348$. 